\title{
Effects of Salicylic Acid and Calcium Chloride on Heat Tolerance in Rhododendron 'Fen Zhen Zhu'
}

\author{
Huifei Shen, Bing Zhao ${ }^{1}$, Jingjing Xu, Xizi Zheng, and Wenmei Huang \\ College of Landscape Architecture and Arts, Northwest A\&F University, Yangling, 712100 Shaanxi, \\ People's Republic of China
}

\begin{abstract}
AdDitional INDEX WORDs. injurious level, withered leaf, chlorophyll content, antioxidant enzymes, malondialdehyde, soluble protein

ABSTRACT. Rhododendrons (Rhododendron) are ornamental plants that exhibit poor thermotolerance. Salicylic acid (SA) and $\mathrm{Ca}^{2+}$ regulate the physiological and biochemical mechanisms in plants adapted to adverse environmental conditions. This study investigated the role of $\mathrm{SA}$ and $\mathrm{CaCl}_{2}$ in managing heat tolerance of Rhododendron 'Fen $\mathrm{Zhen}$ Zhu'. Plants of the triennial Rhododendron 'Fen $\mathrm{Zhen} \mathrm{Zhu}$ ' were pretreated with $\mathrm{SA}$ and $\mathrm{CaCl}_{2}$, alone and combined. Following this pretreatment, the plants were subjected to $38 / 30{ }^{\circ} \mathrm{C}$ (day/night) incubation for 6 days, and then allowed to recover for 20 days under $25 / 17^{\circ} \mathrm{C}$ (day/night) in a chamber. Changes in morphology were observed and recorded. Data were collected on plant chlorophyll content, malondialdehyde (MDA) content, $\mathrm{H}_{2} \mathrm{O}_{2}$ level, antioxidant enzyme activity, and total soluble protein content. The results revealed that the plant growth was considerably affected by heat stress, the leaves became brown and withered, and the plant defoliated. Under heat stress, chlorophyll content and total soluble protein levels decreased. Peroxidase (POD) activity and superoxide dismutase (SOD) also decreased, whereas the $\mathrm{H}_{2} \mathrm{O}_{2}$ and MDA content increased. Individual or combined application of $\mathrm{SA}$ and $\mathrm{CaCl}_{2} \mathrm{had}_{\text {a positive }}$ effect on plant growth, chlorophyll content, total soluble protein levels, and enzymatic antioxidant activity under heat stress. In general, the effect of the combined application of $\mathrm{SA}$ and $\mathrm{CaCl}_{2}$ was superior to individual application. In addition, treatment with high $\mathrm{CaCl}_{2}$ concentrations effectively alleviated the decrease in chlorophyll content. However, at low $\mathrm{SA}$ and $\mathrm{CaCl}_{2}$ concentrations, SOD and $\mathrm{POD}$ activity and total soluble protein accumulation increased whereas MDA and $\mathrm{H}_{2} \mathrm{O}_{2}$ levels decreased. These results suggest that $\mathrm{SA}$ and $\mathrm{CaCl}_{2}$ may interact to alleviate heat stress.
\end{abstract}

Global climate change may not only increase $\mathrm{CO}_{2}$ concentration, but also sustain elevated temperatures (Intergovernmental Panel on Climate Change, 2013; Lavania et al., 2015). As a result, the distribution pattern of plant communities will be negatively affected and the scenario where the vegetation in different landscapes is drastically affected over a period of time might become a reality (Grover et al., 2013). Although some ornamental plants have the capacity to evolve and cope with temperature fluctuations, this capacity might not keep pace with global warming, reduced ornamental value, and economic losses (Tao et al., 2015). Heat stress not only affects the phenotype of a plant, causing leaf etiolation and wilting, but it alters the anatomy, physiology, and photosynthesis capability of plants as well, even at the genetic level (Chen et al., 2014; Mishkind et al., 2009; Perez et al., 2009). Heat stress induces overproduction of reactive oxygen species (ROS) in plant tissues, thus seriously affecting the balance between the generation and degradation of ROS. Furthermore, plants respond quickly to various abiotic stresses by regulating complex physiological, biochemical, and molecular mechanisms for acclimation and adaptation to stress (Chandel et al., 2013; Chen et al., 2014). Antioxidants act as ROS scavengers to mitigate oxidative injury and to maintain metabolic functions; these include antioxidant enzymes and nonenzymatic low molecular weight antioxidant molecules (Semida and Rady, 2014a, 2014b).

Received for publication 2 Feb. 2016. Accepted for publication 6 May 2016. We thank the International Science and Technology Cooperation Foundation (A213021501), the National Natural Science Foundation of China (k305021110), and the Shaanxi Natural Science Foundation (2012JQ3008).

${ }^{1}$ Corresponding author. E-mail: bingbing2003915@163.com.
Heat tolerance can be improved by genetic selection as well as with the use of exogenous regulators, which aid the adaptation of physiological response in plants. SA and $\mathrm{Ca}^{2+}$ are recognized as signal molecules known for their roles in plant adaptation to changing environments (Janda and Ruellan, 2015; Laanemets et al., 2013). SA, a small phenolic compound, plays a significant role in regulating physiological processes in plants involved in response to various abiotic stress such as drought (Nazar et al., 2015), cold (Sibozaa et al., 2014), heat (Boatwright and Karolina, 2013), intense light (Zhao et al., 2011), and salinity (Agami, 2013; Manaa et al., 2014; Rady and Mohamed, 2015). Application of SA enhances the photosynthetic rate and maintains the stability of the cell membrane through regulating enzymatic activity (Ghanta et al., 2014), which eventually alleviated oxidative stress (Wasti et al., 2012), but the underlying mechanism remains unclear (Wang et al., 2014). This effect of SA on oxidative stress response was observed in a variety of plants: Solanum lycopersicum (Manaa et al., 2014; Wasti et al., 2012), Arabidopsis thaliana (Borsani et al., 2001), Vigna radiata (Singh et al., 2014), and Triticum aestivum (Kumar et al., 2015; Li et al., 2013; Zhao et al., 2011). In different $T$. aestivum cultivars, variations in the expression levels of heat stress-associated proteins have been documented (Kumar et al., 2012). In contrast, there are limited studies on heat tolerance of flowers, especially the heat tolerance of Rhododendron.

Several studies have shown that $\mathrm{Ca}^{2+}$ is of pivotal importance for various regulatory mechanisms in plants as a secondary messenger, controlling a variety of cellular processes such as stomatal movements (Hubbard et al., 2012; Laanemets et al., 2013), antioxidant enzyme activity, and lipid peroxidation under multiple stresses (Khan et al., 
2010). Thus, exogenous application of $\mathrm{Ca}^{2+}$ has become an important research topic due to concerns about the effects of climate change on plants. Cytosolic $\mathrm{Ca}^{2+}$ content increases under heat stress, which might alleviate heat injury and initiate cellular repair (Bamberg et al., 1998; Gong et al., 1998). The activities of antioxidant enzymes in plants pretreated with $\mathrm{CaCl}_{2}$ either increase or do not decrease to the same extent as in the control group (Tan et al., 2011). It has been shown that $\mathrm{Ca}^{2+}$ treatment prevents solute leakage from the cytoplasm, stabilizing cell membrane surfaces, and regulating hormone metabolism in plants (Hirschi, 2004). However, the effect of $\mathrm{Ca}^{2+}$ treatment on thermotolerance of Rhododendron is poorly studied.

Individual exogenous application of $\mathrm{SA}$ and $\mathrm{Ca}^{2+}$ in mitigating heat stress has been studied extensively (Manaa et al., 2014). Combination application of $\mathrm{SA}$ and $\mathrm{Ca}^{2+}$ improved growth, photosynthetic pigment concentration, and mineral nutrition in S. lycopersicum during salt stress (Manaa et al., 2014). Studies on SA and $\mathrm{Ca}^{2+}$, individual or combined, for $T$. aestivum under salt stress revealed that the combined application proved more effective in reducing oxidative stress (AlWhaibi et al., 2012). This research suggests that SA and $\mathrm{Ca}^{2+}$ interact to reduce stress. Other studies also support this conclusion (Guo et al., 2015; Xu et al., 2008).

Rhododendron is one of the most popular ornamental plants worldwide, with both medicinal and edible value (Dampc and Luczkiewicz, 2013). At present, genetic variation (Li et al., 2015; Zhao et al., 2012), flowering-related gene manipulation (Cheon et al., 2012), selective breeding of some species (Shen et al., 2015), and the identification of the major chemical constituents in leaf were the main subjects in studies on Rhododendron (Lou et al., 2015). Influenced by genetic factors, this genus is widely distributed at high altitudes, in cold and moist areas. Thus, heat intolerance is a major constraint in Rhododendron cultivation and landscape applications. Rhododendron $\times$ hybridum was obtained by hybridization over several generations: Rhododendron simsii, Rhododendron phoeniceum, Rhododendron indicum, and Rhododendron capitatum. Rhododendron 'Fen Zhen Zhu' is a compact plant, with pink flowers, and an early, long flowering period, from January to March. Despite its high ornamental value, it has poor thermal resistance. A limited number of studies have investigated heat resistance of Rhododendron, and the influence of SA and $\mathrm{Ca}^{2+}$ pretreatment on heat tolerance in ornamental plants, including Rhododendron, has rarely been reported. Because of its poor thermal resistance and difficulty in growing it in gardens, commercial Rhododendron is currently cultivated in greenhouses, thus requiring more energy, manpower, and resources. For these reasons, the influence of $\mathrm{SA}$ and $\mathrm{CaCl}_{2}$ treatments, applied alone and in combination, on Rhododendron 'Fen Zhen Zhu' was assessed by observing changes in physiology and morphology of plants exposed to high temperatures. The results will provide theoretical basis and some practical recommendations for improving thermotolerance in Rhododendron, which can be used to develop management practices for its cultivation in garden and to reduce energy consumption and enhance cultivation in summer. In addition, the effect of $\mathrm{SA}$ and $\mathrm{CaCl}_{2}$ application in Rhododendron will provide basis for further studies on molecular mechanisms responsible for the interaction of the two compounds.

\section{Materials and Methods}

Plant material, growth conditions, and treatments. Rhododendron 'Fen Zhen Zhu', collected from a greenhouse in the city of Dandong, were grown in plastic pots $(12 \mathrm{~cm} \mathrm{high,}$ diameter $16 \mathrm{~cm}$ at the top, and $10 \mathrm{~cm}$ at the bottom) in a greenhouse in Yangling, Shaanxi province, China. The culture substrate was a 1:1 (v:v) mixture of peat and pine needle mulch. In July 2015, plants of similar stature, height $\approx 28-30 \mathrm{~cm}$ and crown $18-21 \mathrm{~cm}$ in diameter, were selected and transferred to a growth chamber $\left[25 / 17^{\circ} \mathrm{C}\right.$ (day/night), $80 \%$ relative humidity, photoperiod of $14 \mathrm{~h}$ light $/ 10 \mathrm{~h}$ dark, and light irradiance of $150 \mu \mathrm{mol} \cdot \mathrm{m}^{-2} \cdot \mathrm{s}^{-1}$ ] for 1 week. A tray was placed under the pots to retain water.

After $7 \mathrm{~d}$, the leaves were sprayed daily until saturation with different concentrations of SA $(0.5,1.0$, and $2.0 \mathrm{~mm})$ and $\mathrm{CaCl}_{2}$ $(3.5,7.0$, and $10.5 \mathrm{~mm})$ solutions alone and in combination, between 0800 and $0900 \mathrm{HR}$, for $3 \mathrm{~d}$ (consecutive). Plants sprayed with water were used as a control. In combined treatments, SA spray was applied first, followed by $\mathrm{CaCl}_{2}$ spray, and left to dry (Wang, 2014). Different treatments are listed in Table 1. After $3 \mathrm{~d}$, all plants were exposed to a temperature of $38 / 30{ }^{\circ} \mathrm{C}$ (day/night) for $6 \mathrm{~d}$, and then allowed to recover at a temperature of $25 / 17^{\circ} \mathrm{C}$ (day/night) until new leaves appeared. The plants were managed regularly and watered frequently to keep the growth substrate moist during the experiment. After $6 \mathrm{~d}$ of heat stress, and $20 \mathrm{~d}$ of recovery period, leaf samples were collected for physiological, biochemical, and phenotypical analysis.

Morphological analysis. Throughout the experiment, the morphology of the plants was observed and rated with Roman numbers I-V based on the level of heat-induced injury (Fig. 1; Table 2).

LeAF CHLOROPhyLl InDEx. The pigments were extracted from fresh leaves of experimental plants using $80 \%$ acetone as described by Lichtenthaler (1987). Absorption of the chlorophyll and carotenoids present in the extract was determined with a spectrophotometer (ultraviolet-2450; Shimadzu, Tokyo,

Table 1. Different treatments of salicylic acid (SA) and/or $\mathrm{CaCl}_{2}$ applied to the leaves of Rhododendron 'Fen Zhen Zhu' for improving heat resistance.

\begin{tabular}{lcc}
\hline & \multicolumn{2}{c}{ Treatments } \\
\cline { 2 - 3 } Treatment no. & SA (mM) & $\mathrm{CaCl}_{2}(\mathrm{mM})$ \\
\hline 1 & 0.0 & 0.0 \\
2 & 0.5 & 0.0 \\
3 & 1.0 & 0.0 \\
4 & 2.0 & 0.0 \\
5 & 0.0 & 3.5 \\
6 & 0.0 & 7.0 \\
7 & 0.0 & 10.5 \\
8 & 0.5 & 3.5 \\
9 & 0.5 & 7.0 \\
10 & 0.5 & 10.5 \\
11 & 1.0 & 3.5 \\
12 & 1.0 & 7.0 \\
13 & 1.0 & 10.5 \\
14 & 2.0 & 3.5 \\
15 & 2.0 & 7.0 \\
16 & 2.0 & 10.5 \\
\hline
\end{tabular}




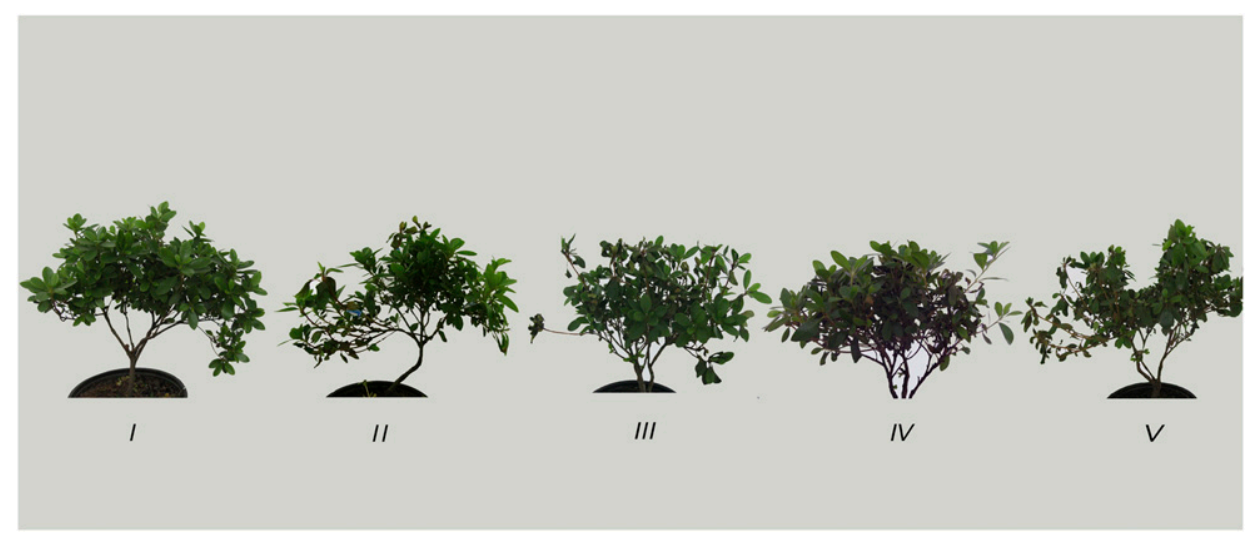

Fig. 1. Injurious levels of heat stress, salicylic acid (SA) and/or $\mathrm{CaCl}_{2}$ application on morphological appearance of Rhododendron 'Fen Zhen Zhu' after 0 and $6 \mathrm{~d}$ of high temperature $\left(38^{\circ} \mathrm{C}\right)$ and $20 \mathrm{~d}$ recovery of optimum temperature $\left(25^{\circ} \mathrm{C}\right)$ : (I) normal growth; (II) $20 \%$ of the leaves became brown and withered; (III) $40 \%$ of the leaves became brown, withered, and defoliated; (IV) $60 \%$ of the leaves became brown and withered; (V) $80 \%$ of the leaves became brown, withered, and defoliated.

Table 2. Different damage level of heat stress, salicylic acid (SA) and/or $\mathrm{CaCl}_{2}$ spray concentration on morphological appearance of Rhododendron 'Fen Zhen Zhu' after 0 and $6 \mathrm{~d}$ of high temperature $\left(38^{\circ} \mathrm{C}\right)$ and $20 \mathrm{~d}$ recovery of optimum temperature $\left(25^{\circ} \mathrm{C}\right)$.

\begin{tabular}{ll}
\hline Level no. & \multicolumn{1}{c}{ Morphological appearance } \\
\hline I & Normal growth \\
II & $20 \%$ of the leaves became brown and withered \\
III & $40 \%$ of the leaves became brown, withered, and defoliated \\
IV & $60 \%$ of the leaves became brown and withered \\
V & $80 \%$ of the leaves became brown, withered, and defoliated
\end{tabular}

Japan). The total content was calculated using the following equations:

$$
\begin{aligned}
\mathrm{C}_{a} & =12.25 A_{663}-2.79 A_{645} \\
\mathrm{C}_{b} & =21.50 A_{645}-5.10 A_{663} \\
\mathrm{C}_{a+b} & =7.15 A_{663}+18.71 A_{645} \\
\mathrm{C}_{x+c} & =\frac{1000 A_{470}-1.82 \mathrm{C}_{a}-85.02 \mathrm{C}_{b}}{198}
\end{aligned}
$$

where $\mathrm{C}_{a}=$ chlorophyll $a ; \mathrm{C}_{b}=$ chlorophyll $b ; \mathrm{C}_{a+b}=$ total chlorophyll; $\mathrm{C}_{x+c}=$ carotenoid; $A_{\lambda}=$ absorbance at $\lambda(\mathrm{nm})$.

ROS AND OSMOREGULATORY SYSTEM. Lipid peroxidation levels were assessed using MDA according to the method described by Madhava Rao and Sresty (2000). Fresh leaves weighing $0.1 \mathrm{~g}$ were homogenized using a prechilled mortar and pestle with $10 \mathrm{~mL} 5 \%(\mathrm{w} / \mathrm{v})$ trichloroacetic acid, and centrifuged at $12,000 g_{\mathrm{n}}$ for $20 \mathrm{~min}$ at $4{ }^{\circ} \mathrm{C}$. The supernatant $(2 \mathrm{~mL})$ was added to a tube containing $2 \mathrm{~mL} 0.67 \%(\mathrm{w} / \mathrm{v})$ thiobarbituric acid. This tube was heated to $100{ }^{\circ} \mathrm{C}$ for $30 \mathrm{~min}$, then rapidly cooled to $4{ }^{\circ} \mathrm{C}$ in an ice bath, and then centrifuged at $10,000 g_{\mathrm{n}}$ for $10 \mathrm{~min}$ at $4{ }^{\circ} \mathrm{C}$. The absorbance of the supernatant was measured at 532 and $600 \mathrm{~nm}$. The MDA content was calculated using the extinction coefficient of $155 \mathrm{~mm}^{-1} \cdot \mathrm{cm}^{-1}$. The $\mathrm{H}_{2} \mathrm{O}_{2}$ and soluble protein content in leaves were measured according to the manufacturer's instructions of the Trizol reagent with $\mathrm{H}_{2} \mathrm{O}_{2}$ and Coomassie brilliant blue (Jiancheng, Nanjing, China). The products were stored at $4{ }^{\circ} \mathrm{C}$.
ENZYMATIC ANTIOXIDANT SYSTEM. A crude enzyme was extracted from the homogenate of $0.1 \mathrm{~g}$ fresh leaf tissue in a $50 \mathrm{~mm}$ potassium phosphate buffer $(\mathrm{pH} 7.8)$ with a precooled mortar and pestle. The homogenate was centrifuged at $12,000 g_{\mathrm{n}}$ for $20 \mathrm{~min}$ at $4{ }^{\circ} \mathrm{C}$. The supernatant was used to determine enzymatic activity. According to the methods described by Giannopolitis and Ries (1977), SOD activity was determined by measuring its ability to inhibit the photoreduction of $50 \%$ nitro blue tetrazolium (NBT). The $3-\mathrm{mL}$ reaction solution included $13 \mathrm{~mm}$ methionine, $75 \mathrm{~nm}$ ethylenediaminetetraacetic acid, $50 \mu \mathrm{M}$ NBT, $1.3 \mu \mathrm{M}$ riboflavin, $50 \mu \mathrm{M}$ potassium phosphate buffer $(\mathrm{pH}$ 7.8), and $50 \mu \mathrm{L}$ enzyme extract. The reaction solution was irradiated under a light irradiance of $50 \mu \mathrm{mol} \cdot \mathrm{m}^{-2} \cdot \mathrm{s}^{-1}$ for $20 \mathrm{~min}$, and the supernatant absorbance was measured at $560 \mathrm{~nm}$; nonirradiated reaction solution was used as a blank. One unit of SOD activity was defined as the amount of enzyme that caused a $50 \%$ inhibition of NBT photoreduction. POD activity was analyzed as described by Chance and Maehly (1955), with slight modifications, the supernatant absorbance was measured at $470 \mathrm{~nm}$. The assay reaction solution contained $0.2 \mathrm{M}$ potassium phosphate buffer ( $\mathrm{pH} 6.0), 30 \%(\mathrm{v} / \mathrm{v}) \mathrm{H}_{2} \mathrm{O}_{2}, 100 \%$ guaiacol solution, and $50 \mu \mathrm{L}$ enzyme extract for a total of $3 \mathrm{~mL}$. One unit of POD activity was defined as the amount of enzyme that oxidized micromoles of guaiacol radical per minute.

Statistical analysis. The data analysis was performed using statistical software (SPSS version 22.0; IBM Corp., Armonk, NY), and Duncan's multiple range test was used to compare treatments when the analysis of variance showed a significant difference between means at $P \leq 0.05$; a probability value less than 0.05 was regarded as statistically significant (Al-Whaibi et al., 2012). Means and standard errors were calculated from three replicates.

\section{Results}

Plant growth. After $6 \mathrm{~d}$ of exposure to heat stress, the plants sprayed with $\mathrm{SA}$ and $\mathrm{CaCl}_{2}$ alone or combined, showed some changes in morphology: the leaves turned brown, withered, and the plants defoliated with different levels of injury (Table 3), depending on the treatments. Thus, the plants treated with exogenous $\mathrm{SA}$ and $\mathrm{CaCl}_{2}$, alone or in combination, were markedly protected from heat-induced growth inhibition. In contrast, the control group had the highest degree of injury among all the treatments, with $80 \%$ of the leaves withering and defoliating. The control group also exhibited the largest damage rate, $25 \%$, compared with its growth rate under optimal temperature. For all the treatments, the results revealed that the damage rate in plants treated with a combination of SA and $\mathrm{CaCl}_{2}$ was lower than that in plants treated with $\mathrm{SA}$ and $\mathrm{CaCl}_{2}$ alone. Treatment groups 8, 9, and 11 improved the most; the damage rate of these plants was only $4.2 \%$.

Pigment content. As presented in Fig. 2, chlorophyll $a$, total chlorophyll, and carotenoid content degraded in most of 
Table 3. Injurious level and damage rate of heat stress, salicylic acid (SA) and/or $\mathrm{CaCl}_{2}$ spray concentration on morphological appearance of Rhododendron 'Fen Zhen Zhu' after 0 and $6 \mathrm{~d}$ of high temperature $\left[38{ }^{\circ} \mathrm{C}(0 \mathrm{~d}\right.$ and $\left.6 \mathrm{~d})\right]$ and $20 \mathrm{~d}$ recovery of optimum temperature $\left[25^{\circ} \mathrm{C}(\mathrm{R} 20 \mathrm{~d})\right]$.

\begin{tabular}{lcccc}
\hline & \multicolumn{3}{c}{$\begin{array}{c}\text { Level of performance } \\
\text { at different times }\end{array}$} & $\begin{array}{c}\text { Damage rate } \\
\text { Rreatment no. }\end{array}$ \\
\cline { 2 - 4 } & 0 d & 6 d & R20 d & \\
\hline 1 & I $^{\mathrm{y}}$ & IV-V & IV & 25.0 \\
2 & I & II & II & 12.5 \\
3 & I & II-III & II & 16.7 \\
4 & I & III & II-III & 20.8 \\
5 & I & II-III & II & 16.7 \\
6 & I & II-III & III & 20.8 \\
7 & I & IV & III & 20.8 \\
8 & I & II & I & 4.2 \\
9 & I & II & I-II & 4.2 \\
10 & I & II & I-II & 8.3 \\
11 & I & II & I-II & 4.2 \\
12 & I & II & I-II & 8.3 \\
13 & I & II-III & II & 8.3 \\
14 & I & II-III & II & 12.5 \\
15 & I & II-III & II & 16.7 \\
16 & I & III & II-III & 16.7 \\
\hline
\end{tabular}

${ }^{\text {zTreatments described in Table } 1 .}$

${ }^{y}$ Different injurious level: I = normal growth; II $=20 \%$ of the leaves became brown and withered; III $=40 \%$ of the leaves became brown, withered, and defoliated; IV $=60 \%$ of the leaves became brown and withered; $\mathrm{V}=80 \%$ of the leaves became brown, withered, and defoliated.

the treatments. The total pigment content before the stress treatment was higher than after the stress period, although there was a slight rebound in the content in some treatments after the recovery period. Chlorophyll $b$ content decreased initially and then increased (Fig. 2B). The pigment content in all plants treated with exogenous application of SA and $\mathrm{CaCl}_{2}$, both alone and combined, was significantly greater compared with that in the control $(P \leq 0.05)$, whatever the treatment, except for chlorophyll $b$ in treatment 10 before the exposure to heat stress. Particularly, plants treated with $\mathrm{SA}$ and $\mathrm{CaCl}_{2}$ alone showed an enhanced chlorophyll $a$, chlorophyll $b$, total chlorophyll, and carotenoid content before the heat treatment compared with plants treated with both $\mathrm{SA}$ and $\mathrm{CaCl}_{2}$. The single treatments with either $\mathrm{SA}$ or $\mathrm{CaCl}_{2}$ decreased pigment loss triggered by the exposure to heat stress, especially in plants exposed to treatment 6 in which chlorophyll $a$, chlorophyll $b$, total chlorophyll, and carotenoid contents decreased by $30.0 \%$, $30.5 \%, 30.1 \%$, and $39.9 \%$ respectively. The smallest variation in pigment range was observed in plants treated with the combination of SA and $\mathrm{CaCl}_{2}: 4.7 \%$ in treatment 15 for chlorophyll $a, 4.6 \%$ in treatment 10 for chlorophyll $b, 2.0 \%$ in treatment 13 for total chlorophyll, and 3.5\% in treatment 15 for carotenoid. Thus, combined application of $\mathrm{SA}$ and $\mathrm{CaCl}_{2}$ was more efficient in relieving the adverse effects of heat stress on pigments. However, during the restoration stage and compared with the pigment content in plants grown under optimal temperature, the largest decline in pigment content occurred in treatment 3 for chlorophyll $a$ (by 6.3\%) and total chlorophylls (by 4.9\%), in treatment 13 for chlorophyll $b$ (by $5.3 \%$ ), and in treatment 15 for carotenoids (by 18.5\%). The smallest decline in pigment content was observed in treatment 6 for chlorophyll $a$ (by $-10.1 \%$ ), total chlorophylls (by 10.7\%), and carotenoids (by -29.9\%) and in treatment 14 for chlorophyll $b$ (by $24.8 \%$ ), when compared with the pigment content in plants not exposed to heat stress. Therefore, a simple application of $\mathrm{CaCl}_{2}$ effectively protected chlorophyll $a$, total chlorophylls, and carotenoid content. According to the significance analysis, treatments with $\mathrm{SA}$ and $\mathrm{CaCl}_{2}$ alone or in combination significantly enhanced the pigment content under heat stress at all time periods $(P \leq 0.05)$. There were significant differences between the treatments $(P \leq 0.05)$ : treatment 6 resulted in the highest pigment content before heat stress treatment, whereas the plants in treatment 15 were better in morphology after the heat stress treatment and $20 \mathrm{~d}$ of recovery.

ROS sYsTEM. As shown in Table 4 , heat stress significantly increased the content of MDA [by $22.7 \%(P \leq 0.05)]$, which is the final product in membrane lipid peroxidation, compared with the control plants in treatment 1 . However, although the MDA content decreased after $20 \mathrm{~d}$ of recovery, it was $6.6 \%$ higher compared with its initial level before heat stress. In addition, the MDA content in leaves was significantly higher compared with that in other treatments, whereas treatment 8 showed the largest decline in MDA content, by $26.9 \%$ to $0.092 \mu \mathrm{M} \cdot \mathrm{g}^{-1}$ after $6 \mathrm{~d}$ of heat stress. The MDA content in treatment 8 was still lower compared with that of other treatments after $20 \mathrm{~d}$ of recovery. According to the significance analysis, a combined $\mathrm{SA}$ and $\mathrm{CaCl}_{2}$ application was superior to their individual application, although the significance of difference was poor $(P \leq 0.05)$.

Similarly, before exposure to heat stress, the combined treatment of $\mathrm{SA}$ and $\mathrm{CaCl}_{2}$ was superior, substantially decreasing the $\mathrm{H}_{2} \mathrm{O}_{2}$ levels in leaves at the beginning of heat stress by $30.2 \%, 27.2 \%, 19.1 \%, 21.7 \%$, and $17.4 \%$ in treatments 8 to 12 , respectively, compared with that in the control (Table 5). Furthermore, treatments 2, 5, and 6 also decreased significantly the levels of $\mathrm{H}_{2} \mathrm{O}_{2}$ compared with that in the control $(P \leq 0.05)$. After a 6-d incubation period at high temperature, the content of $\mathrm{H}_{2} \mathrm{O}_{2}$ increased in most treatments, except in treatments 12 and 15 , in which its content decreased. Overall, the application of both $\mathrm{SA}$ and $\mathrm{CaCl}_{2}$ in $\mathrm{H}_{2} \mathrm{O}_{2}$ level showed a smaller decline, but not in treatment 14. The content of $\mathrm{H}_{2} \mathrm{O}_{2}$ in all treatments was also significantly lower than that in the control after $20 \mathrm{~d}$ of recovery $(P \leq 0.05)$, except in treatment 4 .

Osmoregulatory SYSTEM. The total soluble protein in leaves of Rhododendron 'Fen Zhen Zhu' increased from the beginning of heat stress in all treatments except in treatments 5 , 6 , and 7 , which showed a minor decline in total soluble protein content after $20 \mathrm{~d}$ of recovery, and in treatments $1,13,14$, and 16 , in which the total soluble protein content increased after an initial slight reduction (Fig. 3). With the exception of treatments 4,5 , and 8 , the soluble protein content in each group was significantly higher than that in the control $(P \leq 0.05)$, regardless of the time period. The highest growth rate was observed in treatment 4 , in which the growth rate increased by $56.5 \%$ under heat stress compared with that under optimal temperature conditions. Although the control showed the largest decline in total soluble protein content $(19.3 \%)$ compared with that before the stress, after the $20 \mathrm{~d}$ recovery period, it increased by $25 \%$ compared with that before the stress, which was similar to treatments 14 and 16. Among the plants treated with individual exogenous application of SA and $\mathrm{CaCl}_{2}$, plants in treatment 6 showed significantly higher growth compared with those in 

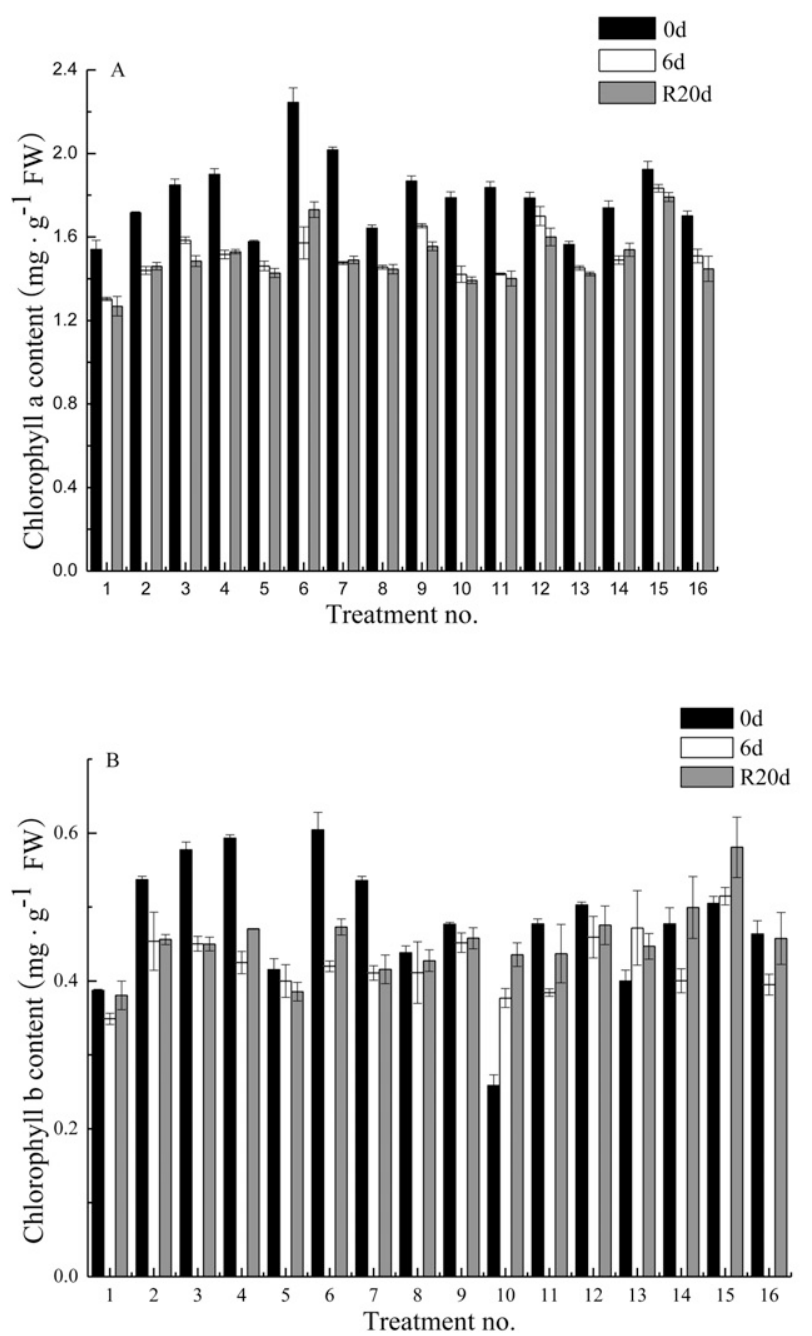
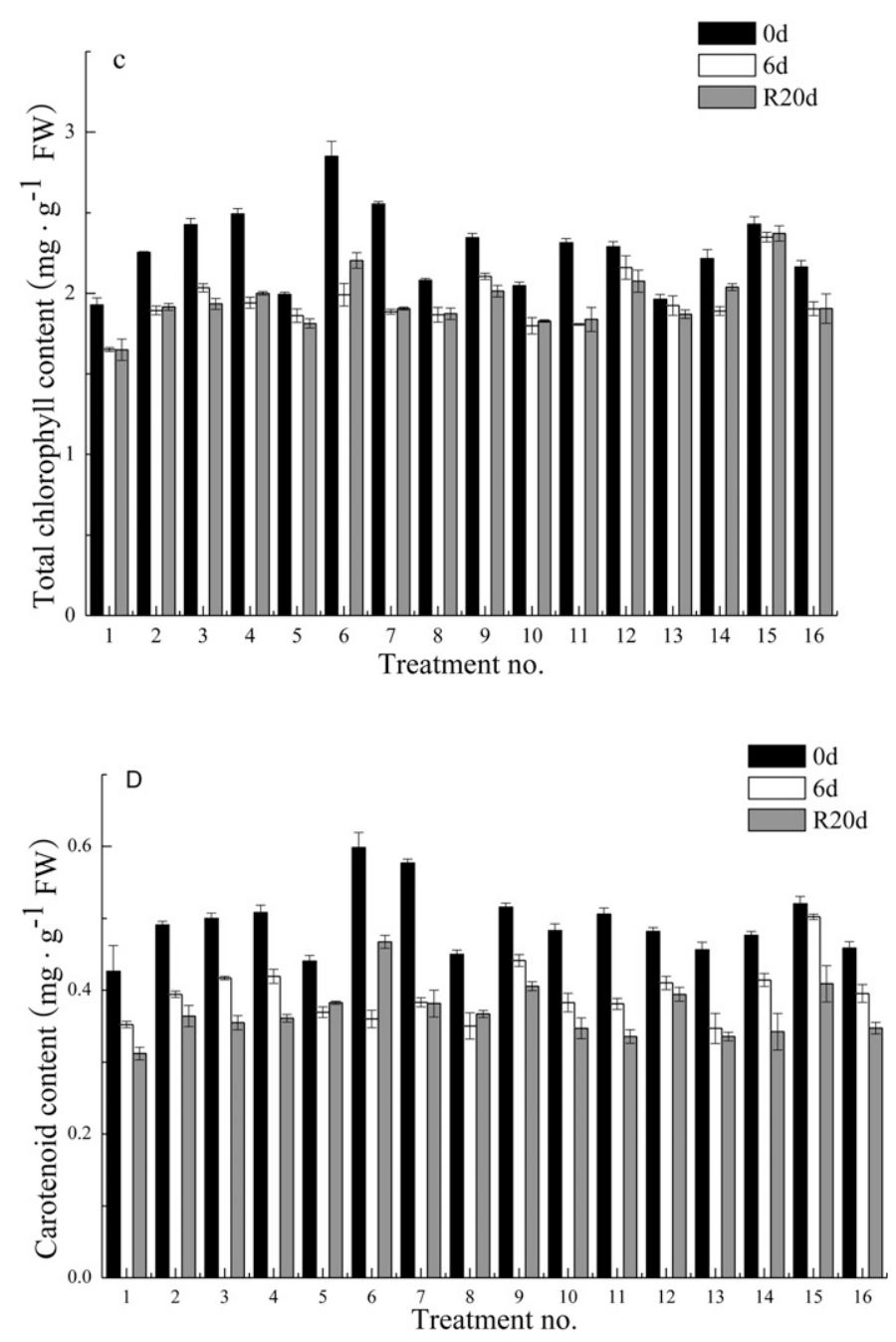

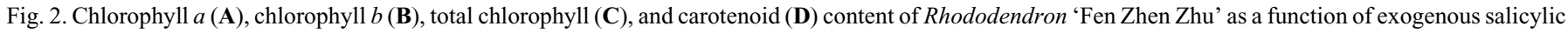
acid (SA) and/or $\mathrm{CaCl}_{2}$ concentration during heat stress and recovery. Treatment numbers are described in Table $1 ; 0 \mathrm{~d}=$ before the heat stress $\left(38^{\circ} \mathrm{C}\right), 6 \mathrm{~d}=$ after the heat stress $\left(38^{\circ} \mathrm{C}\right), \mathrm{R} 20 \mathrm{~d}=$ after $20 \mathrm{~d}$ recovery $\left(25^{\circ} \mathrm{C}\right)$. Values within same column show significant differences at $P \leq 0.05$ significance level among treatments according to the Duncan's multiple range test. Data are means of three replicates \pm SE.

other treatments under heat stress $(P \leq 0.05)$; there was no significant difference between treatments 6 and 7 after $6 \mathrm{~d}$ of exposure to heat stress $(P>0.05)$. In addition, treatments 9,12 , and 15 were superior to others in total soluble protein at different times.

Antioxidant enzyme system. SOD and POD activities in leaves were examined to investigate whether a change in MDA and $\mathrm{H}_{2} \mathrm{O}_{2}$ content is associated with higher antioxidase activity. As shown in Tables 6 and 7, SOD and POD activities decreased initially and then increased with time in most treatments. Heat stress significantly decreased the SOD activity, and the decrease was greater in treatments with individual or combined exogenous application of SA and $\mathrm{CaCl}_{2}$ (Table 6). The SOD activity in the control group was reduced by $8.7 \%$ under heat stress compared with that in plants exposed to $0 \mathrm{~d}$ of stress. After the 20 -d recovery period, it reached only $\approx 94.7 \%$ of that observed in the control. The SOD activity was increased in the plants pretreated with SA and $\mathrm{CaCl}_{2}$, alone or in combination. In treatment 10 , the SOD activity reached the highest level, increasing by $10.5 \%$ before the stress compared with that in untreated plants, and maintained its high-activity level regardless of whether the plants were under stress conditions or in the recovery. Meanwhile, the SOD activity in treatment 8 was significantly higher than that in the control $(P \leq 0.05)$, and treatments 9,10 , and 14 had a better effect on SOD activity under heat stress. Lower concentrations of SA or $\mathrm{CaCl}_{2}$ were sustained among treatments. In addition, treatments 2 and 5 have a better effect in SA and $\mathrm{CaCl}_{2}$ respectively on improving SOD activity. Similar to the SOD pattern, the POD activity was also affected in leaves exposed to heat (Table 7). The treatments induced the POD activity; the increase in POD activity was significant in plants treated with $\mathrm{SA}$ (treatment 2) and $\mathrm{CaCl}_{2}$ (treatment 5) $(P \leq 0.05)$. However, combined SA and $\mathrm{CaCl}_{2}$ application is more beneficial to enhance POD activity, especially in treatment 11 , which increased POD activity by $6.8 \%$ before the stress treatment compared with the control; it was the smallest decline in POD activity in all treatments after the stress incubation, and recovered well. Regardless of the time, POD and SOD activities increased more after the simultaneous application of $\mathrm{SA}$ and $\mathrm{CaCl}_{2}$ compared with that in plants with individual exogenous $\mathrm{SA}$ and $\mathrm{CaCl}_{2}$ application. 
Table 4. Effects of heat stress, salicylic acid (SA) and/or $\mathrm{CaCl}_{2}$ application on malondialdehyde (MDA) content of Rhododendron 'Fen Zhen Zhu' after 0 and $6 \mathrm{~d}$ of high temperature $\left[38^{\circ} \mathrm{C}(0 \mathrm{~d}\right.$ and $\left.6 \mathrm{~d})\right]$ and $20 \mathrm{~d}$ recovery of optimum temperature $\left[25^{\circ} \mathrm{C}(\mathrm{R} 20 \mathrm{~d})\right]$.

\begin{tabular}{llll}
\hline & \multicolumn{1}{c}{ MDA content [mean $\left.\pm \mathrm{SE}\left(\mu \mathrm{M} \cdot \mathrm{g}^{-1} \mathrm{FW}\right)\right]$} \\
\cline { 2 - 4 } Treatment no. $^{\mathrm{z}}$ & $0 \mathrm{~d}$ & $0.212 \pm 0.004 \mathrm{a}$ & $\mathrm{R} 20 \mathrm{~d}$ \\
\hline 1 & $0.173 \pm 0.005 \mathrm{a}^{\mathrm{y}}$ & $0.117 \pm 0.002 \mathrm{i}$ & $0.185 \pm 0.008 \mathrm{a}$ \\
2 & $0.130 \pm 0.001 \mathrm{gh}$ & $0.139 \pm 0.001 \mathrm{def}$ & $0.145 \pm 0.001 \mathrm{hij}$ \\
3 & $0.144 \pm 0.002 \mathrm{ef}$ & $0.144 \pm 0.001 \mathrm{cdef}$ & $0.178 \pm 0.001 \mathrm{ab}$ \\
4 & $0.156 \pm 0.001 \mathrm{c}$ & $0.136 \pm 0.002 \mathrm{efg}$ & $0.162 \pm 0.001 \mathrm{de}$ \\
5 & $0.154 \pm 0.000 \mathrm{~cd}$ & $0.158 \pm 0.001 \mathrm{~b}$ & $0.168 \pm 0.001 \mathrm{~cd}$ \\
6 & $0.156 \pm 0.001 \mathrm{c}$ & $0.149 \pm 0.001 \mathrm{bcd}$ & $0.177 \pm 0.000 \mathrm{ef}$ \\
7 & $0.156 \pm 0.001 \mathrm{c}$ & $0.092 \pm 0.005 \mathrm{j}$ & $0.139 \pm 0.001 \mathrm{j}$ \\
8 & $0.126 \pm 0.002 \mathrm{~h}$ & $0.126 \pm 0.005 \mathrm{ghi}$ & $0.149 \pm 0.000 \mathrm{gh}$ \\
9 & $0.135 \pm 0.002 \mathrm{~g}$ & $0.133 \pm 0.006 \mathrm{fgh}$ & $0.168 \pm 0.001 \mathrm{~cd}$ \\
10 & $0.148 \pm 0.001 \mathrm{de}$ & $0.137 \pm 0.003 \mathrm{defg}$ & $0.140 \pm 0.001 \mathrm{ig}$ \\
11 & $0.142 \pm 0.001 \mathrm{f}$ & $0.142 \pm 0.005 \mathrm{def}$ & $0.147 \pm 0.001 \mathrm{ghi}$ \\
12 & $0.146 \pm 0.001 \mathrm{ef}$ & $0.154 \pm 0.003 \mathrm{bc}$ & $0.152 \pm 0.001 \mathrm{fgh}$ \\
13 & $0.148 \pm 0.002 \mathrm{de}$ & $0.124 \pm 0.003 \mathrm{hi}$ & $0.146 \pm 0.001 \mathrm{ghij}$ \\
14 & $0.149 \pm 0.002 \mathrm{de}$ & $0.145 \pm 0.005 \mathrm{cde}$ & $0.153 \pm 0.001 \mathrm{fg}$ \\
15 & $0.149 \pm 0.003 \mathrm{de}$ & $0.146 \pm 0.004 \mathrm{cde}$ & $0.170 \pm 0.000 \mathrm{c}$ \\
16 & $0.166 \pm 0.001 \mathrm{~b}$ & &
\end{tabular}

zTreatments described in Table 1.

${ }^{\mathrm{y}}$ Means followed by different lower case letter indicate significant among treatments based on Duncan's multiple range test at $P=0.05$ (n $=3$ ).

Table 5. Effects of heat stress, salicylic acid (SA) and/or $\mathrm{CaCl}_{2}$ application on hydrogen peroxide $\left(\mathrm{H}_{2} \mathrm{O}_{2}\right)$ content of Rhododendron 'Fen $\mathrm{Zhen}$ Zhu' after 0 and $6 \mathrm{~d}$ of high temperature $\left[38^{\circ} \mathrm{C}(0 \mathrm{~d}\right.$ and $\left.6 \mathrm{~d})\right]$ and $20 \mathrm{~d}$ recovery of optimum temperature $\left[25^{\circ} \mathrm{C}(\mathrm{R} 20 \mathrm{~d})\right]$.

\begin{tabular}{llll}
\hline & \multicolumn{1}{c}{$\mathrm{H}_{2} \mathrm{O}_{2}$ content $\left[\mathrm{mean} \pm \mathrm{sE}\left(\mathrm{mM} \cdot \mathrm{g}^{-1}\right.\right.$ protein FW)] } \\
\cline { 2 - 4 } Treatment no. $^{\mathrm{z}}$ & \multicolumn{1}{c}{$0 \mathrm{~d}$} & \multicolumn{1}{c}{$6 \mathrm{~d}$} & $372.453 \pm 12.041 \mathrm{a}$ \\
\hline 1 & $342.924 \pm 19.0449 \mathrm{a}^{\mathrm{y}}$ & $271.764 \pm 13.002 \mathrm{fgh}$ & $261.281 \pm 12.585 \mathrm{de}$ \\
2 & $254.796 \pm 9.495 \mathrm{~cd}$ & $300.090 \pm 9.409 \mathrm{cdefg}$ & $275.911 \pm 4.327 \mathrm{cde}$ \\
4 & $289.531 \pm 14.512 \mathrm{abcd}$ & $340.804 \pm 10.878 \mathrm{~b}$ & $325.471 \pm 18.099 \mathrm{abc}$ \\
5 & $330.165 \pm 7.693 \mathrm{ab}$ & $282.121 \pm 12.651 \mathrm{efgh}$ & $257.930 \pm 19.696 \mathrm{de}$ \\
6 & $268.968 \pm 12.742 \mathrm{~cd}$ & $307.105 \pm 6.364 \mathrm{bcdef}$ & $274.753 \pm 5.540 \mathrm{cde}$ \\
7 & $287.390 \pm 28.231 \mathrm{bcd}$ & $320.846 \pm 8.779 \mathrm{bcde}$ & $290.197 \pm 15.058 \mathrm{bcde}$ \\
8 & $292.080 \pm 8.885 \mathrm{abcd}$ & $252.363 \pm 13.097 \mathrm{~h}$ & $243.027 \pm 15.438 \mathrm{e}$ \\
9 & $239.240 \pm 3.905 \mathrm{~d}$ & $262.030 \pm 10.891 \mathrm{gh}$ & $241.089 \pm 16.690 \mathrm{e}$ \\
10 & $249.648 \pm 0.940 \mathrm{~cd}$ & $287.939 \pm 5.190 \mathrm{defgh}$ & $266.713 \pm 18.181 \mathrm{de}$ \\
11 & $277.545 \pm 16.052 \mathrm{bcd}$ & $280.143 \pm 13.232 \mathrm{fgh}$ & $260.288 \pm 6.649 \mathrm{de}$ \\
12 & $268.313 \pm 28.848 \mathrm{~cd}$ & $271.537 \pm 10.589 \mathrm{fgh}$ & $256.502 \pm 15.602 \mathrm{de}$ \\
13 & $283.070 \pm 24.018 \mathrm{bcd}$ & $307.957 \pm 5.220 \mathrm{bcdef}$ & $281.444 \pm 19.758 \mathrm{bcde}$ \\
14 & $303.863 \pm 17.006 \mathrm{abc}$ & $325.614 \pm 20.285 \mathrm{bcd}$ & $270.216 \pm 10.886 \mathrm{de}$ \\
15 & $293.978 \pm 13.234 \mathrm{abcd}$ & $303.813 \pm 7.222 \mathrm{bcdef}$ & $306.558 \pm 14.264 \mathrm{bcd}$ \\
16 & $303.815 \pm 13.744 \mathrm{abc}$ & $331.922 \pm 22.791 \mathrm{bc}$ & $328.884 \pm 28.260 \mathrm{ab}$ \\
\hline
\end{tabular}

${ }^{\mathrm{z}}$ Treatments described in Table 1.

${ }^{\mathrm{y}}$ Means followed by different lower case letter indicate significant among treatments based on Duncan's multiple range test at $P=0.05$ (n $=3$ ).

The SOD and POD activities in all treated plants were significantly higher than those in untreated plants $(P \leq 0.05)$.

\section{Discussion}

The genus Rhododendron includes heat-sensitive plant species, with the optimum growth temperature between 10 and $25{ }^{\circ} \mathrm{C}$. However, during summer months in China, Rhododendrons must endure high temperatures of over $35^{\circ} \mathrm{C}$, which increases the cost of management practices employed in commercial cultivation of these plants in greenhouses. The plants may alter their morphology and physiology under heat stress, decreasing their ornamental values. In the present study,
Rhododendron 'Fen Zhen Zhu' plants exposed to heat stress developed the following signs of stress: yellowing of the leaf tips, browning and drying of the leaves, and different levels of injury depending on the treatment (Fig. 1; Table 3). Such morphological changes might have occurred due to a substantial decline in light-harvesting pigment content (Fig. 2), which increased the damaging effects of ROS (Tables 4 and 5). This mechanism could be used to extend heat tolerance. Chloroplasts, mitochondria, and peroxisomes are the major sources of ROS production in plant cells. Production of ROS by these sources is enhanced by unfavorable environmental conditions that limit $\mathrm{CO}_{2}$ fixation, leading to an increase in photoinhibition and overproduction of superoxide radicals and $\mathrm{H}_{2} \mathrm{O}_{2}$ (Radwan, 
2012). Similar findings were reported in three cultivars of Raphanus sativus exposed to $40{ }^{\circ} \mathrm{C}$ (Chen et al., 2014). In addition, the total soluble protein content decreased during heat stress (Fig. 3) as did the SOD and POD activities (Tables 6 and 7). Furthermore, the 2-month-long observations revealed that the plants that were subjected to heat stress, in particular those treated with SA and $\mathrm{CaCl}_{2}$, were growing better than those that were not subjected to heat stress.

It has long been hypothesized that $\mathrm{SA}$ and $\mathrm{Ca}^{2+}$ protect against various adverse environmental conditions by regulating the antioxidant levels through activation or inhibition of the

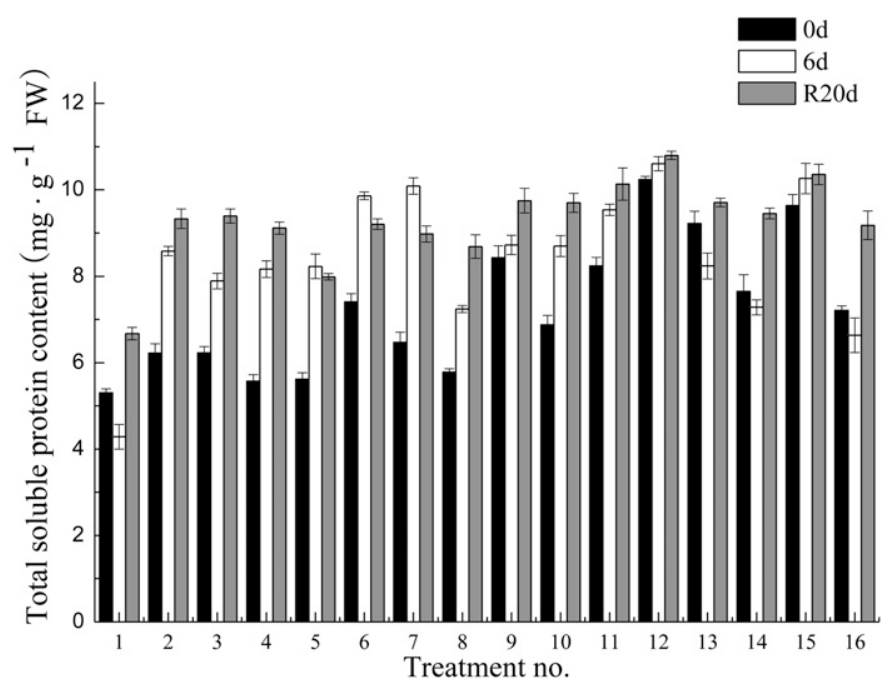

Fig. 3. Total soluble protein content of Rhododendron 'Fen Zhen Zhu' as a function of exogenous salicylic acid (SA) and/or $\mathrm{CaCl}_{2}$ concentration during heat stress and recovery Treatment numbers are described in Table 1;0 $\mathrm{d}=$ before the heat stress $\left(38^{\circ} \mathrm{C}\right), 6 \mathrm{~d}=$ after the heat stress $\left(38^{\circ} \mathrm{C}\right) ; \mathrm{R} 20 \mathrm{~d}=$ after $20 \mathrm{~d}$ recovery $\left(25^{\circ} \mathrm{C}\right)$. Values within same column show significant differences at $P \leq 0.05$ significance level among treatments according to the Duncan's multiple range test. Data are means of three replicates \pm SE. antioxidant enzymatic system, which is responsible for scavenging generated ROS (Apel and Hirt, 2004; Farooq et al., 2008; Kumar et al., 2012; Tan et al., 2011). Decreased MDA, $\mathrm{H}_{2} \mathrm{O}_{2}$, and chlorophyll content and increased activities of SOD and POD could be the reason for diminished growth performance of the experimental plants under heat stress. Exogenous application of SA and $\mathrm{CaCl}_{2}$ alleviated the heat-induced reduction in growth of experimental plants (Figs. 2-3; Tables 3-7). Similar improvement in growth by exogenous SA and $\mathrm{CaCl}_{2}$ treatment, individual and combined, was reported in $S$. lycopersicum grown under heat stress conditions (Manaa et al., 2014). The decrease in injury levels may be due to the inhibited decline in chlorophyll content and increased accumulation of MDA and $\mathrm{H}_{2} \mathrm{O}_{2}$. The experimental results showed that pigment content decreased during heat treatment; however, Rhododendron leaves sprayed with SA and $\mathrm{CaCl}_{2}$, alone or in combination, $3 \mathrm{~d}$ before exposure to heat stress showed fewer or no injuries, which helped reduce pigment loss induced by heat stress. Specifically, treatment $15\left(2.0 \mathrm{~mm} \mathrm{SA}+7.0 \mathrm{~mm} \mathrm{CaCl}_{2}\right)$ prevented most the loss of pigments before and after stress treatment. In addition, before the heat stress treatment, the greatest decrease in pigment content was observed in treatment $6\left(7.0 \mathrm{~mm} \mathrm{CaCl}_{2}\right)$. Slight decrease in chlorophyll $a$ and carotenoid contents was observed in treatment 15 . Similarly, slight decrease in chlorophyll $b$ and total chlorophyll contents was observed in treatment $10\left(0.5 \mathrm{~mm} \mathrm{SA}+10.5 \mathrm{~mm} \mathrm{CaCl}_{2}\right)$ and treatment $13(1.0 \mathrm{~mm} \mathrm{SA}+10.5 \mathrm{~mm} \mathrm{CaCl} 2)$, respectively. These treatments contained a high concentration of $\mathrm{Ca}^{2+}$, which may be because SA-treated cells can maintain $\mathrm{Ca}^{2+}$ homeostasis and antioxidant systems under heat stress, and increased cytosolic $\mathrm{Ca}^{2+}$ protected the chloroplast structure (Wang and $\mathrm{Li}, 2006$ ). Lipid peroxidation levels were assessed by MDA, the final product of lipid peroxidation. $\mathrm{H}_{2} \mathrm{O}_{2}$ is produced during lipid catabolism as a side product of fatty acid oxidation. MDA and $\mathrm{H}_{2} \mathrm{O}_{2}$ play an important role in plant tissue metabolism, but any excess production of MDA and $\mathrm{H}_{2} \mathrm{O}_{2}$ is harmful, especially to the membranes. Accumulation of elevated $\mathrm{H}_{2} \mathrm{O}_{2}$ and MDA

Table 6. Effects of heat stress, salicylic acid (SA) and/or $\mathrm{CaCl}_{2}$ application on superoxide dismutase (SOD) activity of Rhododendron 'Fen Zhen Zhu' after 0 and $6 \mathrm{~d}$ of high temperature $\left[38^{\circ} \mathrm{C}(0 \mathrm{~d}\right.$ and $\left.6 \mathrm{~d})\right]$ and $20 \mathrm{~d}$ recovery of optimum temperature $\left[25^{\circ} \mathrm{C}(\mathrm{R} 20 \mathrm{~d})\right]$.

\begin{tabular}{llll}
\hline & \multicolumn{3}{c}{ SOD activity [mean $\left.\pm \mathrm{SE}\left(\mathrm{U} \cdot \mathrm{g}^{-1} \cdot \mathrm{min}^{-1} \mathrm{FW}\right)\right]$} \\
\cline { 2 - 4 } Treatment no. $^{\mathrm{z}}$ & \multicolumn{1}{c}{$0 \mathrm{~d}$} & \multicolumn{1}{c}{$6 \mathrm{~d}$} & $\mathrm{R} 20 \mathrm{~d}$ \\
\hline 1 & $331.866 \pm 4.582 \mathrm{e}^{\mathrm{y}}$ & $305.092 \pm 8.818 \mathrm{~g}$ & $314.218 \pm 1.685 \mathrm{~d}$ \\
2 & $340.647 \pm 3.773 \mathrm{de}$ & $330.434 \pm 3.716 \mathrm{ef}$ & $343.582 \pm 3.975 \mathrm{bc}$ \\
3 & $347.259 \pm 0.471 \mathrm{bcde}$ & $328.145 \pm 3.645 \mathrm{f}$ & $335.298 \pm 6.118 \mathrm{c}$ \\
4 & $342.145 \pm 2.947 \mathrm{cde}$ & $324.318 \pm 0.623 \mathrm{f}$ & $334.332 \pm 5.559 \mathrm{c}$ \\
5 & $349.431 \pm 8.518 \mathrm{abcde}$ & $338.403 \pm 7.263 \mathrm{cdef}$ & $352.286 \pm 5.987 \mathrm{ab}$ \\
6 & $341.040 \pm 3.905 \mathrm{cde}$ & $327.533 \pm 3.893 \mathrm{f}$ & $338.545 \pm 3.676 \mathrm{bc}$ \\
7 & $344.510 \pm 10.298 \mathrm{cde}$ & $329.206 \pm 1.838 \mathrm{ef}$ & $337.019 \pm 3.801 \mathrm{c}$ \\
8 & $359.095 \pm 2.758 \mathrm{abc}$ & $358.551 \pm 4.994 \mathrm{a}$ & $351.708 \pm 2.868 \mathrm{ab}$ \\
9 & $363.020 \pm 11.188 \mathrm{ab}$ & $351.344 \pm 1.526 \mathrm{abc}$ & $345.685 \pm 6.643 \mathrm{abc}$ \\
10 & $366.669 \pm 4.396 \mathrm{a}$ & $354.917 \pm 3.040 \mathrm{ab}$ & $359.301 \pm 1.209 \mathrm{a}$ \\
11 & $350.772 \pm 1.505 \mathrm{abcd}$ & $337.875 \pm 3.461 \mathrm{cdef}$ & $345.576 \pm 3.400 \mathrm{abc}$ \\
12 & $345.048 \pm 2.589 \mathrm{cde}$ & $333.829 \pm 2.797 \mathrm{def}$ & $348.781 \pm 3.251 \mathrm{abc}$ \\
13 & $365.502 \pm 4.466 \mathrm{a}$ & $348.071 \pm 3.784 \mathrm{abcd}$ & $346.618 \pm 5.313 \mathrm{abc}$ \\
14 & $356.077 \pm 3.456 \mathrm{abcd}$ & $345.352 \pm 3.860 \mathrm{abcd}$ & $352.007 \pm 5.188 \mathrm{ab}$ \\
15 & $355.114 \pm 3.832 \mathrm{abcd}$ & $342.966 \pm 5.808 \mathrm{bcde}$ & $348.731 \pm 1.715 \mathrm{abc}$ \\
16 & $342.828 \pm 4.537 \mathrm{cde}$ & $337.465 \pm 3.205 \mathrm{cdef}$ & $336.758 \pm 2.814 \mathrm{c}$ \\
\hline
\end{tabular}

${ }^{\mathrm{z}}$ Treatments described in Table 1.

${ }^{\mathrm{y}}$ Means followed by different lower case letter indicate significant among treatments based on Duncan's multiple range test at $P=0.05$ (n $=3$ ). 
Table 7. Effects of heat stress, salicylic acid (SA) and/or $\mathrm{CaCl}_{2}$ application on peroxidase (POD) activity of Rhododendron 'Fen Zhen Zhu' after 0 and $6 \mathrm{~d}$ of high temperature $\left[38^{\circ} \mathrm{C}(0 \mathrm{~d}\right.$ and $\left.6 \mathrm{~d})\right]$ and $20 \mathrm{~d}$ recovery of optimum temperature $\left[25^{\circ} \mathrm{C}(\mathrm{R} 20 \mathrm{~d})\right]$.

\begin{tabular}{llrr}
\hline & \multicolumn{3}{c}{ POD activity [mean $\left.\pm \mathrm{SE}\left(\mathrm{U} \cdot \mathrm{g}^{-1} \cdot \mathrm{min}^{-1} \mathrm{FW}\right)\right]$} \\
\cline { 2 - 4 } Treatment no. $^{\mathrm{z}}$ & $0 \mathrm{~d}$ & $6 \mathrm{~d}$ & $\mathrm{R} 20 \mathrm{~d}$ \\
\hline 1 & $99.544 \pm 5.460 \mathrm{f}$ & $75.497 \pm 3.274 \mathrm{~h}$ & $87.879 \pm 2.227 \mathrm{~d}$ \\
2 & $138.867 \pm 8.997 \mathrm{abcde}$ & $119.079 \pm 6.786 \mathrm{cdefg}$ & $122.964 \pm 9.565 \mathrm{abc}$ \\
3 & $121.516 \pm 8.154 \mathrm{def}$ & $100.861 \pm 2.486 \mathrm{~g}$ & $110.281 \pm 2.752 \mathrm{bcd}$ \\
4 & $126.972 \pm 10.441 \mathrm{cde}$ & $107.838 \pm 5.875 \mathrm{fg}$ & $111.839 \pm 6.891 \mathrm{bcd}$ \\
5 & $133.299 \pm 9.383 \mathrm{bcde}$ & $118.928 \pm 6.523 \mathrm{cdeg}$ & $126.641 \pm 13.669 \mathrm{abc}$ \\
6 & $120.561 \pm 9.741 \mathrm{ef}$ & $103.270 \pm 2.884 \mathrm{~g}$ & $105.069 \pm 7.661 \mathrm{~cd}$ \\
7 & $123.305 \pm 9.926 \mathrm{def}$ & $112.887 \pm 9.317 \mathrm{efg}$ & $120.241 \pm 11.492 \mathrm{abc}$ \\
8 & $153.680 \pm 11.405 \mathrm{abc}$ & $138.889 \pm 5.526 \mathrm{abc}$ & $135.412 \pm 9.657 \mathrm{ab}$ \\
9 & $157.221 \pm 7.423 \mathrm{ab}$ & $132.040 \pm 6.606 \mathrm{abcde}$ & $140.262 \pm 3.104 \mathrm{a}$ \\
10 & $150.788 \pm 6.668 \mathrm{abc}$ & $140.619 \pm 15.530 \mathrm{abc}$ & $142.450 \pm 8.903 \mathrm{a}$ \\
11 & $161.490 \pm 6.932 \mathrm{a}$ & $150.440 \pm 3.760 \mathrm{a}$ & $147.572 \pm 6.923 \mathrm{a}$ \\
12 & $151.424 \pm 11.476 \mathrm{abc}$ & $135.079 \pm 3.354 \mathrm{abcd}$ & $126.241 \pm 7.814 \mathrm{abc}$ \\
13 & $148.331 \pm 3.972 \mathrm{abcd}$ & $128.066 \pm 5.268 \mathrm{bcdef}$ & $125.315 \pm 4.117 \mathrm{abc}$ \\
14 & $155.808 \pm 6.993 \mathrm{ab}$ & $143.363 \pm 6.100 \mathrm{ab}$ & $137.548 \pm 6.739 \mathrm{ab}$ \\
15 & $148.087 \pm 4.050 \mathrm{abcd}$ & $135.241 \pm 7.010 \mathrm{abcd}$ & $130.443 \pm 5.828 \mathrm{abc}$ \\
16 & $139.560 \pm 1.945 \mathrm{abcde}$ & $114.167 \pm 2.487 \mathrm{defg}$ & $125.376 \pm 11.414 \mathrm{abc}$ \\
\hline
\end{tabular}

zTreatments described in Table 1.

${ }^{\mathrm{y}}$ Means followed by different lower case letter indicate significant among treatments based on Duncan's multiple range test at $P=0.05$ (n $=3$ ).

levels during heat stress was recorded (Tables 4 and 5), suggesting the presence of oxidative species in 'Fen Zhen Zhu' leaves. However, the levels of MDA and $\mathrm{H}_{2} \mathrm{O}_{2}$ after SA and $\mathrm{CaCl}_{2}$ pretreatment, alone or in combination, were lower compared with the control, and application of $\mathrm{SA}$ and $\mathrm{CaCl}_{2}$ in combination had a greater effect on the inhibition of MDA and $\mathrm{H}_{2} \mathrm{O}_{2}$, especially in treatment $8\left(0.5 \mathrm{~mm} \mathrm{SA}+3.5 \mathrm{~mm} \mathrm{CaCl}_{2}\right)$, which lowered the levels of ROS in plants, suggesting that SA and $\mathrm{CaCl}_{2}$ might have interacted in managing plant stress.

However, improving growth by applying SA and $\mathrm{CaCl}_{2}$ alone or in combination onto the plants during heat stress could be correlated with a substantial increase in total soluble protein content (Fig. 3), especially in plants exposed to treatments 12 and 15 , both of which contained $7.0 \mathrm{mM} \mathrm{CaCl}_{2}$. The considerable increase in total soluble protein content in our findings could be due to a sufficient calcium concentration, which is required at all stages of plant growth and development and which plays a vital role in regulating the polar growth of cells and tissues as well as the plant adaptation to various stress factors.

Various enzymatic scavenging activities, particularly for ROS, are found in different cellular compartments. The enzymatic ROS-scavenging pathway, an antioxidant defense mechanism, helps to counteract ROS and protect cells from oxidative damage (Radwan, 2012). SOD acts as a first line of defense against ROS by converting superoxides into $\mathrm{H}_{2} \mathrm{O}_{2}$, and thus decreasing their toxic effects to the cell (Wang et al., 2004). $\mathrm{H}_{2} \mathrm{O}_{2}$ has to be further detoxified by POD and catalase/ ascorbate POD to water and oxygen (Shah et al., 2001). $\mathrm{H}_{2} \mathrm{O}_{2}$ detoxification prevents the oxidation of biological molecules and destruction of cells (Liochev and Fridovich, 1994). In the present study, exogenous application of SA and $\mathrm{CaCl}_{2}$, alone or combined, could induce changes in SOD and POD activities similar to those in the control. A large amount of $\mathrm{Ca}^{2+}$ influx from apoplasts to protoplasts after $10 \mathrm{~h}$ of SA induction has been reported (Guo et al., 2015). In addition, the combined application of SA and $\mathrm{CaCl}_{2}$ had a greater effect on SOD and POD activities. The effectiveness of the combined treatments is optimal if the mixture contains at least $0.5 \mathrm{~mm} \mathrm{SA}$ or $3.5 \mathrm{~mm} \mathrm{CaCl}_{2}$. This might be because a lower concentration of SA induced an increase in $\mathrm{Ca}^{2+}$ content, which led to the inhibition of SOD and POD activities. The study also revealed that treatment 5 was significantly higher than the application of $\mathrm{CaCl}_{2}$ alone in improving SOD and POD activities $(P \leq 0.05)$.

In conclusion, the present study showed that the heat stress causes yellowing of leaf tips and browning and drying of leaf parts in Rhododendron 'Fen Zhen Zhu'. In addition, the contents of chlorophyll and total soluble protein decreased, the MDA and $\mathrm{H}_{2} \mathrm{O}_{2}$ contents increased, and the activities of SOD and POD increased under heat stress. The plant morphology and physiology showed a slight improvement after $20 \mathrm{~d}$ of recovery. The exogenous application of $\mathrm{SA}$ and $\mathrm{CaCl}_{2}$, alone or combined, improved plant growth by regulating the same physiological and biochemical mechanisms that respond to heat stress. Application of SA and $\mathrm{CaCl}_{2}$ is effective in alleviating the decrease in chlorophyll content at higher concentrations of $\mathrm{CaCl}_{2}$. At lower concentrations of $\mathrm{SA}$ and $\mathrm{CaCl}_{2}$, the activity of SOD and POD increased as well as the accumulation of total soluble protein. This resulted in further scavenging of ROS and increased MDA and $\mathrm{H}_{2} \mathrm{O}_{2}$.

The present results provide a new perspective to the use of $\mathrm{SA}$ and $\mathrm{CaCl}_{2}$ in the protection of Rhododendron 'Fen Zhen Zhu' from injuries induced by heat stress. This method could save energy costs in greenhouse management. Thus, the measurement of related physiological indexes and exploration of signal transduction pathways is a powerful tool to improve plant tolerance to abiotic stress.

\section{Literature Cited}

Agami, R.A. 2013. Alleviating the adverse effects of $\mathrm{NaCl}$ stress in maize seedlings by pretreating seeds with salicylic acid and 24epibrassinolide. S. Afr. J. Bot. 88:171-177.

Al-Whaibi, M.H., M.H. Siddiqui, and M.O. Basalah. 2012. Salicylic acid and calcium-induced protection of wheat against salinity. Protoplasma 249:769-778. 
Apel, K. and H. Hirt. 2004. Reactive oxygen species: Metabolism, oxidative stress, and signal transduction. Annu. Rev. Plant Biol. 55:373-399.

Bamberg, J.B., J.P. Palta, L.A. Peterson, M. Martin, and A.R. Krueger. 1998. Fine screening potato species germplasm for tuber calcium. Amer. J. Potato Res. 75:181-186.

Boatwright, J.L. and P.M. Karolina. 2013. Salicylic acid: An old hormone up to new tricks. Mol. Plant Pathol. 14:623-634.

Borsani, O., V. Valpuesta, and M.A. Botella. 2001. Evidence for a role of salicylic acid in the oxidative damage generated by $\mathrm{NaCl}$ and osmotic stress in Arabidopsis seedlings. Plant Physiol. 126:1024-1030.

Chance, B. and A.C. Maehly. 1955. Assay of catalase and peroxidases. Methods Enzymol. 11:764-775.

Chandel, G., M. Dubey, and R. Meena. 2013. Differential expression of heat shock proteins and heat stress transcription factor genes in rice exposed to different levels of heat stress. J. Plant Biochem. Biotechnol. 22:277-285.

Chen, W.L., W.J. Yang, H.F. Lo, and D.M. Yeh. 2014. Physiology, anatomy, and cell membrane thermostability selection of leafy radish (Raphanus sativus var. oleiformis Pers.) with different tolerance under heat stress. Scientia Hort. 179:367-375.

Cheon, K.S., A. Nakatsuka, K. Tasaki, and N. Kobayashi. 2012. Seasonal changes in the expression pattern of flowering-related genes in evergreen azalea 'Oomurasaki' (Rhododendron $\times$ pulchrum). Scientia Hort. 134:176-184.

Dampc, A. and M. Luczkiewicz. 2013. Rhododendron tomentosum (Ledum palustre). A review of traditional use based on current research. Fitoterapia 85:130-143.

Farooq, M., T. Aziz, S.M.A. Basra, A. Wahid, A. Khaliq, and M.A. Cheema. 2008. Exploring the role of calcium to improve chilling tolerance in hybrid maize. J. Agron. Crop Sci. 194:350-359.

Ghanta, S., R. Datta, D. Bhattacharyya, R. Sinha, D. Kumar, S. Hazra, A.B. Mazumdar, and S. Chattopadhyay. 2014. Multistep involvement of glutathione with salicylic acid and ethylene to combat environmental stress. J. Plant Physiol. 171:940-950.

Giannopolitis, C.N. and S.K. Ries. 1977. Superoxide dismutases: I. Occurrence in higher plants. Plant Physiol. 59:309-314.

Gong, M., A.H. van der Luit, M.R. Kinght, and A.J. Trewavas. 1998. Heat-shock-induced changes in intracellular $\mathrm{Ca}^{2+}$ level in tobacco seedlings in relation to thermotolerance. Plant Physiol. 116:429-437.

Grover, A., D. Mittal, M. Negi, and D. Lavania. 2013. Generating high temperature tolerant transgenic plants: Achievements and challenges. Plant Sci. 205:38-47.

Guo, H.B., N. Zhu, M.K. Deyholos, J. Liu, X.R. Zhang, and J.E. Dong. 2015. Calcium mobilization in salicylic acid-induced Salvia miltiorrhiza cell cultures and its effect on the accumulation of rosmarinic acid. Appl. Biochem. Biotechnol. 175:2689-2702.

Hirschi, K.D. 2004. The calcium conundrum. Both versatile nutrient and specific signal. Plant Physiol. 136:2438-2442.

Hubbard, K.E., R.S. Siegel, G. Valerio, B. Brandt, and J.I. Schroeder. 2012. Abscisic acid and $\mathrm{CO}_{2}$ signalling via calcium sensitivity priming in guard cells, new CDPK mutant phenotypes and a method for improved resolution of stomatal stimulus-response analyses. Ann. Bot. 109:5-17. Intergovernmental Panel on Climate Change. 2013. Climate change: The physical science basis. Cambridge Univ. Press, Cambridge, UK. Janda, M. and E. Ruellan. 2015. Magical mystery tour: Salicylic acid signalling. Environ. Expt. Bot. 114:117-128.

Khan, M.N., M.H. Siddiqui, F. Mohammad, M. Naeem, and M.M.A. Khan. 2010. Calcium chloride and gibberellic acid protect linseed (Linum usitatissimum $\mathrm{L}$.) from $\mathrm{NaCl}$ stress by inducing antioxidative defence system and osmoprotectant accumulation. Acta Physiol. Plant. 32:121-132.

Kumar, R.R., S. Goswami, S.K. Sharma, K. Singh, K.A. Gadpayle, N. Kumar, G.K. Rai, M. Singh, and R.D. Rai. 2012. Protection against heat stress in wheat involves change in cell membrane stability, antioxidant enzymes, osmolyte, $\mathrm{H}_{2} \mathrm{O}_{2}$ and transcript of heat shock protein. Intl. J. Plant Physiol. Biochem. 4:83-91.
Kumar, R.R., S.K. Sharma, S. Goswami, P. Verma, K. Singh, N. Dixit, P. Himanshu, C. Viswanathan, and R.D. Rai. 2015. Salicylic acid alleviates the heat stress-induced oxidative damage of starch biosynthesis pathway by modulating the expression of heat-stable genes and proteins in wheat (Triticum aestivum). Acta Physiol. Plant. 37:143. Laanemets, K., B. Brandt, J.L. Li, E. Merilo, Y.F. Wang, M.M. Keshwani, S.S. Taylor, H. Kollist, and J.I. Schroeder. 2013. Calciumdependent and -independent stomatal signaling network and compensatory feedback control of stomatal opening via $\mathrm{Ca}^{2+}$ sensitivity priming. Plant Physiol. 163:504-513.

Lavania, D., A. Dhingra, M.H. Siddiqui, M.H. Al-Whaibi, and A. Grover. 2015. Current status of the production of high temperature tolerant transgenic crops for cultivation in warmer climates. Plant Physiol. Biochem. 86:100-108.

Li, G.Z., X.Q. Peng, L.T. Wei, and G.Z. Kang. 2013. Salicylic acid increases the contents of glutathione and ascorbate and temporally regulates the related gene expression in salt-stressed wheat seedlings. Gene 529:321-325.

Li, M.W., S.F. Chen, S. Shi, Z. Zhang, W.B. Liao, W. Wu, R.C. Zhou, and Q. Fan. 2015. High genetic diversity and weak population structure of Rhododendron jinggangshanicum, a threatened endemic species in Mount Jinggangshan of China. Biochem. Syst. Ecol. 58:178-186.

Lichtenthaler, H.K. 1987. Chlorophylls and carotenoids: Pigments of photosynthetic biomembranes. Methods Enzymol. 148:350-382.

Liochev, S.I. and I. Fridovich. 1994. Paraquat diaphorases in Escherichia coli. Free Radic. Biol. Med. 16:555-559.

Lou, X.W., Q.H. Lin, G.Y. Zhang, W.Y. Liu, F. Feng, and W. Qu. 2015. Identification and characterization of three new flavonoids from Rhododendron dauricum. Chin. J. Nat. Med. 13:0628-0633.

Manaa, A., E. Gharbi, H. Mimouni, S. Wasti, S. Aschi-Smiti, S. Lutts, and H. Ben Ahmed. 2014. Simultaneous application of salicylic acid and calcium improves salt tolerance in two contrasting tomato (Solanum lycopersicum) cultivars. S. Afr. J. Bot. 95:32-39.

Mishkind, M., J.E.M. Vermeer, E. Darwish, and T. Munnik. 2009. Heat stress activates phospholipase D and triggers PIP accumulation at the plasma membrane and nucleus. Plant J. 60:10-21.

Nazar, R., S. Umar, N.A. Khan, and O. Sareer. 2015. Salicylic acid supplementation improves photosynthesis and growth in mustard through changes in proline accumulation and ethylene formation under drought stress. S. Afr. J. Bot. 98:84-94.

Perez, D.E., J.S. Hoyer, A.I. Johnson, Z.R. Moody, J. Lopez, and N.J. Kaplinsky. 2009. BOBBER1 is a noncanonical Arabidopsis small heat shock protein required for both development and thermotolerance. Plant Physiol. 151:241-252.

Radwan, D.E.M. 2012. Salicylic acid induced alleviation of oxidative stress caused by clethodim in maize (Zea mays L.) leaves. Pestic. Biochem. Physiol. 102:182-188.

Rady, M.M. and G.F. Mohamed. 2015. Modulation of salt stress effects on the growth, physio-chemical attributes and yields of Phaseolus vulgaris L. plants by the combined application of salicylic acid and Moringa oleifera leaf extract. Scientia Hort. 193:105-113. Rao, K.V.M. and T.V.S. Sresty. 2000. Antioxidative parameters in the seedlings of pigeonpea [Cajanus cajan (L.) Millspaugh] in response to $\mathrm{Zn}$ and Ni stresses. Plant Sci. 157:113-128.

Semida, W.M. and M.M. Rady. 2014a. Presoaking in 24-epibrassinolide or salicylic acid improves seed germination, seedling growth, and anti-oxidant capacity in Phaseolus vulgaris L. grown under $\mathrm{NaCl}$ stress. J. Hort. Sci. Biotech. 89:338-344.

Semida, W.M. and M.M. Rady. 2014b. Presoaking application of propolis and maize grain extracts alleviates salinity stress in common bean (Phaseolus vulgaris L.). Scientia Hort. 168:210-217.

Shah, K., R.G. Kumar, S. Verma, and R.S. Dubey. 2001. Effect of cadmium on lipid peroxidation, superoxide anion generation and activities of antioxidant enzymes in growing rice seedlings. Plant Sci. $161: 1135-1144$.

Shen, S.K., F.Q. Wu, G.S. Yang, Y.H. Wang, and W.B. Sunday. 2015. Seed germination and seedling emergence in the extremely endangered 
species Rhododendron protistum var. giganteum: the world's largest Rhododendron. Flora 216:65-70.

Sibozaa, X.I., I. Bertling, and A.O. Odindo. 2014. Salicylic acid and methyl jasmonate improve chilling tolerance in cold-stored lemon fruit (Citrus limon). J. Plant Physiol. 171:1722-1731.

Singh, V.P., J. Kumar, S. Singh, and S.M. Prasad. 2014. Dimethoate modifies enhanced UV-B effects on growth, photosynthesis and oxidative stress in mung bean (Vigna radiata L.) seedlings: Implication of salicylic acid. Pestic. Biochem. Physiol. 116:13-23.

Tan, W., Q.W. Meng, M. Brestic, K. Olsovska, and X.H. Yang. 2011. Photosynthesis is improved by exogenous calcium in heat-stressed tobacco plants. J. Plant Physiol. 168:2063-2071.

Tao, Z.X., Q.S. Ge, H.J. Wang, and J.H. Dai. 2015. Phenological basis of determining tourism seasons for ornamental plants in central and eastern China. J. Geogr. Sci. 25:1343-1356.

Wang, L.J. and S.H. Li. 2006. Salicylic acid induced heat or cold tolerance in relation to $\mathrm{Ca}^{2+}$ homeostasis and antioxidant systems in young grape plants. Plant Sci. 170:685-694.

Wang, R. 2014. Studies on the effects of heat-resistant agent in improving the heat tolerance of Rhododendron delavayi. MS Thesis, Zhongkai Univ. Agr. Eng., Guangzhou, PR China. (in Chinese).
Wang, Y.H., P. Zhang, X. Hou, P. Su, H. Zhao, and S. Liu. 2014. Foliar-applied salicylic acid alleviates heat and high light stress induced photoinhibition in wheat (Triticum aestivum) during the grain filling stage by modulating the psbA gene transcription and antioxidant defense. Plant Growth Regulat. 73:289-297.

Wang, Y.S., J. Wang, Z.M. Yang, B. Lu, Q.Y. Wang, S.Q. Li, Y.P. Lu, S.H. Wang, and X. Sunday. 2004. Salicylic acid modulates aluminum induced oxidative stress in roots of Cassia tora L. Bot. Stud. 46:819-828. Wasti, S., H. Mimouni, S. Smiti, E. Zid, and H. Ben Ahmed. 2012. Enhanced salt tolerance of tomatoes by exogenous salicylic acid applied through rooting medium. OMICS 16:200-207.

Xu, Q., X. Xu, Y. Zhao, K. Jiao, S.J. Herber, and L. Hao. 2008. Salicylic acid, hydrogen peroxide and calcium-induced saline tolerance associated with endogenous hydrogen peroxide homeostasis in naked oat seedlings. Plant Growth Regulat. 54:249-259.

Zhao, B., Z.F. Yin, M. Xu, and Q.C. Wang. 2012. AFLP analysis of genetic variation in wild populations of five Rhododendron species in Qinling Mountain in China. Biochem. Syst. Ecol. 45:198-205.

Zhao, H.J., X.J. Zhao, P.F. Ma, Y.X. Wang, W.W. Hu, L.H. Li, and Y.D. Zhao. 2011. Effects of salicylic acid on protein kinase activity and chloroplast D1 protein degradation in wheat leaves subjected to heat and high light stress. Acta Ecol. Sin. 31:259-263. 